\title{
SUNSHINE RECORDERS: A COMPARATIVE STUDY OF THE BURNING-GLASS AND THERMOMETRIC SYSTEMS
}

\author{
By Charles F. Brooks and Eleanor S. Brooks
}

Blue Hill Meteorological Observatory, Harvard University

(Manuscript received 9 April 1947)

(Paper presented 28 December 1946 at Annual Meeting, A.M.S., Cambridge, Massachusetts)

\begin{abstract}
Sunshine duration is recorded in most countries by the Campbell-Stokes burning glass (CS) but in the United States by a thermometric type (US).

CS and US instruments were exposed together and compared at Blue Hill Observatory. The average values of insolation at which the CS and US begin and cease to register were estimated from Blue Hill pyrheliometer records to be $0.33 \mathrm{cal} \mathrm{cm}^{-2} \mathrm{~min}^{-1}$ (CS) and $0.37 \mathrm{cal} \mathrm{cm}^{-2} \mathrm{~min}^{-1}$ (US) for the two instruments tested. However, the US usually exceeds the CS in summer because it responds to diffuse radiation while the CS does not.

Low-sun corrections are added to the US record by the U.S. Weather Bureau before tabulation. The US corrected record is longer than the CS record, which is not increased by a low-sun correction.

Two sets of conversion values were obtained: $(1)$ from the monthly low-sun corrections at various stations and the direct comparison of the instruments at Blue Hill, (2) from comparison of long CS and US (corrected) records of paired Canadian and United States stations and the Blue Hill and Boston pair.

The value to be added to convert CS to US (corrected) is greatest in summer and least in winter. The annual conversion value is a percentage of sunshine duration increasing from 11 per cent in the northern United States to 14 per cent in the south.
\end{abstract}

\section{Introduction}

Records of sunshine duration for the United States cannot be readily compared with those of other American countries or of Europe, because the U.S. Weather Bureau uses a different type of instrument and a different method of evaluation. The Weather Bureau's instrument is a type of black-bulb thermometer that records from the combined effect of diffuse and direct sunshine. The Bureau adds an annual average of approximately one hour a day (5-20 per cent) to the recorded duration in order to include sunshine immediately after sunrise and before sunset that is too weak to activate the instrument. Practically all other countries use the burning-glass (Campbell-Stokes) type of sunshine recorder, which records only bright, direct sunshine; and no addition is made for dim sunshine.

The object of this study is to compare the performance of the United States recorder (hereafter abbreviated ' $U S$ ') with the Campbell-Stokes instrument ('CS'), and to consider the different methods of reduction of data, in order to facilitate interconversion. Thereby, the sunshine data for the United States may be made comparable with records elsewhere, and a more accurate basis established for world sunshine maps.

When annual sunshine duration is to be expressed as the percentage of that astronomically possible for the latitude, a common practice in dealing with the CS consists of computing the ratio of actual bright sunshine to the possible duration, which includes not only bright but also dim sunshine hours when the sun is near the horizon. This procedure seems unsound as an indirect measure of cloudiness, from either a physical or a climatological point of view. ${ }^{1}$

\section{Description and comparison of instruments}

The Campbell-Stokes sunshine recorder (fig. 1) is manufactured mainly in Great Britain and is used almost exclusively throughout the British Empire, in Europe, and in South and Central America. With this instrument, the duration of bright sunshine is recorded as a scorched or burnt line on a chemically treated time card by means of a spherical lens acting as a burning glass. The Meteorological Office, London, has prepared full details regarding the instrument, cards, exposure, adjustments, and reading and a bibliography ${ }^{2}$ and has published instructions for observers (Meteorological Office, 1934). (See also Glasspoole and Hancock, 1936.) The CS recorders are subject to minor errors of focus or orientation, perfect adjustment not often being found in common practice. Moreover, the transparency

${ }^{1}$ At Blue Hill Observatory the percentage of the possible is derived from the ratio of the recorded hours of bright sunshine to the period when bright sunshine is possible in clear weather. From the total of the interval between sunrise and sunset a period varying with the seasons is subtracted to get the duration of possible bright sunshine.

2 Meteorological Office, London, "Memorandum [to International Climatological Commission], The Campbell-Stokes sunshine recorder," 25 pp. (typed), 2 appendices, 11 figs., 1932. 
of the glass sphere varies slightly, not only between different spheres but also with age, and the focusing power of this spherical lens may not be uniform. Curtis (1898) found the records of CS instruments at different

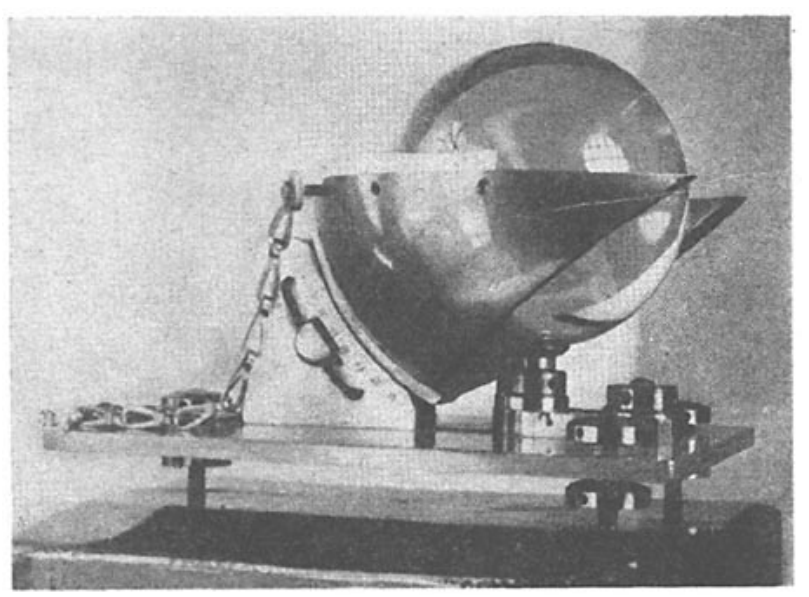

Fig. 1. The Campbell-Stokes burning-glass sunshine-duration recorder (reproduced from Meteorological Office ${ }^{2}$ ).

observatories in Britain readily comparable within 3 per cent. Braak (1937), in Holland, found a 5 per cent change in one instrument in 2 years, and steady differences of $4,8,10-12$, and even 16 per cent between a standard and old instruments. One with a new sphere differed 3 per cent from standard. Differences in reading procedure introduced a discrepancy of 8 per cent at one station and 15-20 per cent at another. Lastly, it is difficult to standardize the card with regard to ease of -burning. In Braak's experience, however, those of British manufacture were quite uniform. A 53-day comparison of the Blue Hill Observatory station instrument with two others in 1932 showed no appreciable differences, however. The new, smaller 'Universal' CS recorded 1.4 per cent less than the station instrument.

Curtis (1898) emphasizes that the CS instrument is not intended to be an actinometer, and the registration of the duration of light is not its function; it is only intended to act when the sun's rays have attained a certain degree of heating power.

If it is agreed to define that limit as the degree of solar radiation which, when concentrated upon a bluish tinted card by a spherical crown gláss lens 4 inches in diameter, is competent to produce a brown mark upon the card, I do not think it possible that any sunshine, the warmth of which is able to produce an appreciable effect upon either animal or vegetable life, is likely to escape registration.

The estimated value of this minimum intensity which can be registered by the CS is $0.3 \mathrm{cal} \mathrm{min}^{-1}$ per square centimeter of normal surface, a figure usually reached only when the sun is $5^{\circ}$ or more above the horizon. It should be remembered that the $\mathrm{CS}$ registers only direct sunlight, not the total radiation from sun and sky, and that diffuse radiation alone may exceed $1 \mathrm{cal} \mathrm{cm}^{-2} \mathrm{~min}^{-1}$ at midday in summer (see section 3 ).

The $\dot{U}$. S. Weather Bureau thermometric sunshineduration recorder (fig. 2).-For its extensive network of stations, the U.S. Weather Bureau has for half a century used a recorder adapted in 1891 by Maring from an instrument by Leslie and later improved slightly by Marvin (Maring, 1897; Marvin, 1941). It is based on the differential heating of blackened and clear bulbs of an air thermometer enclosed in a vacuum. These bulbs are separated by a column of mercury and alcohol that closes an electric circuit when solar radiation overheats the air in the black bulb and pushes the mercury along the tube far enough to intercept two wires stuck through the glass. Too much air in the bulb will make a positive error in the registration.

"The inclination of the recorder will be adjusted at such an angle that the mercury column will just close the electric circuit during the times when the disk of the sun can be just faintly seen through the clouds" (Marvin, 1941). This determination is to be made in spring or fall, but at best is not an exact standard.

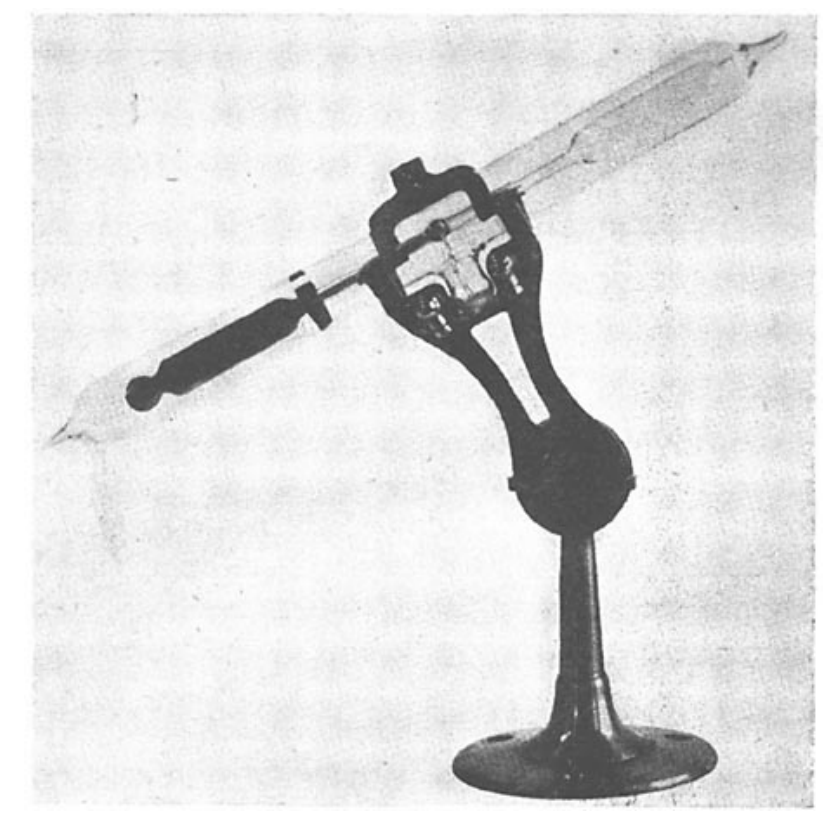

FIG. 2. The U. S. Weather Bureau, Maring-Marvin thermometric sunshine-duration recorder.

Like the CS, this instrument is subject to errors arising from faulty installation and adjustment and fails to record the pale sunlight experienced when the sun is within $5^{\circ}$ of the horizon. In general, the US instrument is somewhat less sensitive than the CS, which averaged 0.8 hours a day (15 per cent) more sunshine in a test at Blue Hill. Unlike the CS, the US instrument is affected by both direct and indirect insolation; therefore, the US record is interrupted less readily by brief periods of partial cloudiness. 


\section{Differences between US and CS recorders}

Comparisons between the CS and US instruments were made at Blue Hill Observatory in 1932 and from November 1939 to March 1942 (see table 1). The US instrument first used in this series appeared incorrect and was replaced at the end of May 1941 by a new recorder carefully adjusted in accordance with Weather Bureau instructions. Instrument 1 (' $\mathrm{US}_{1}$ '), however, was probably more representative of those in general use than instrument 2 (' $\mathrm{US}_{2}$ '). The CS and US instruments were exposed side by side on the Blue Hill tower.

Fig. 3 presents the differences (table 1) as two curves, roughly parallel, both showing that, relative to the US, the CS instrument records highest in winter. Instrument 2 was used as standard in the comparisons which follow. It is difficult to standardize the US recorder. A sudden change of level in a Weather Bureau record may accompany the introduction of a new instrument. Note the curves (fig. 3, lower) comparing the Blue Hill CS with US instruments at Boston.

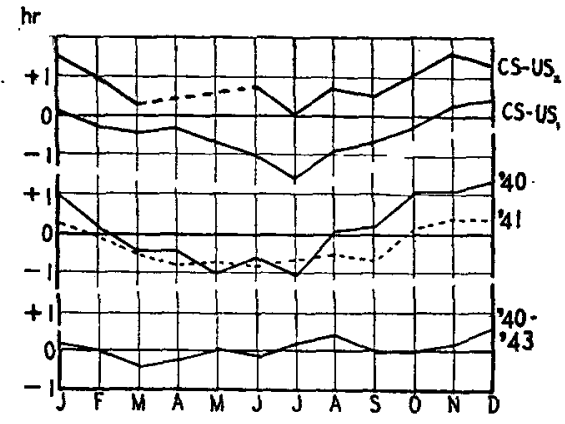

FIG. 3. Annual course of difference in daily duration of sunshine, CS - US. Two upper curves, CS compared with two US recorders at Blue Hill. Three lower curves, $\mathrm{CS}$ at Blue Hill compared with various US recorders at the East Boston airport separately for 1940 and 1941, and combined for the period 1940-1943.

More detailed daily values for June, September, and December, 1941, and March 1942 are presented in table 2, while table 3 shows the daily course of sunshine. The hourly variation in CS - US at Blue Hill resembles the seasonal variation, CS - US being

TABLE 1. Mean daily difference in hours of sunshine recorded: CS - US at Blue Hill, Milton, Mass.

\begin{tabular}{|c|c|c|c|c|c|c|c|c|c|c|c|c|c|}
\hline & Jan. & Feb. & March & April & May & June & July & Aug. & Sept. & Oct. & Nov. & Dec. & Year \\
\hline $\mathrm{CS}-\mathrm{US}_{1}\left\{\begin{array}{l}1939 \\
1940 \\
1941\end{array}\right.$ & $\begin{array}{l}0.1 \\
0.0\end{array}$ & $\begin{array}{r}-0.3 \\
0.0\end{array}$ & $\begin{array}{c}(-0.8) \\
-0.1\end{array}$ & $\begin{array}{l}-0.5 \\
-0.2\end{array}$ & -0.7 & -1.0 & -1.6 & -0.9 & -0.7 & 0.3 & $\begin{array}{l}0.1 \\
0.4\end{array}$ & $\begin{array}{l}0.3 \\
0.5\end{array}$ & -0.3 \\
\hline $\mathrm{CS}-\mathrm{US}_{2}\left\{\begin{array}{l}1941 \\
1942\end{array}\right.$ & 1.5 & 1.0 & 0.3 & & & 0.7 & 0.0 & 0.7 & 0.5 & 1.0 & 1.6 & 1.3 & +0.8 \\
\hline
\end{tabular}

TABle 2. Daily values of sunshine hours at Blue Hill, Milton, Mass.

\begin{tabular}{|c|c|c|c|c|c|c|c|c|}
\hline Day & \multicolumn{2}{|c|}{ March 1942} & \multicolumn{2}{|c|}{ June 1941} & \multicolumn{2}{|c|}{ September 1941} & \multicolumn{2}{|c|}{ CS December 1941} \\
\hline 1 & 5.7 & 0.4 & 0.0 & 0.0 & 9.7 & 0.0 & 6.9 & 3.2 \\
\hline 2 & 5.2 & -0.3 & 6.8 & -0.1 & $1 \ddot{1.6}$ & 0.6 & 0.0 & 0.0 \\
\hline 3 & 0.3 & 0.0 & 10.9 & -0.1 & 11.7 & 0.7 & 7.4 & 1.3 \\
\hline 4 & 5.9 & 0.6 & 0.5 & -2.0 & 6.3 & -0.8 & 7.8 & 1.7 \\
\hline 5 & 2.4 & -1.9 & 0.0 & 0.0 & 0.0 & 0.0 & 3.1 & -0.1 \\
\hline 6 & 0.0 & 0.0 & 9.6 & 0.7 & 10.4 & 0.7 & 6.1 & 0.8 \\
\hline 7 & 8.2 & -0.1 & 11.1 & 1.9 & 11.2 & 0.5 & 2.8 & 1.2 \\
\hline 8 & 8.3 & -0.1 & 9.8 & 0.6 & 11.5 & 0.7 & 3.2 & 0.9 \\
\hline 9 & 1.1 & 0.4 & 13.6 & 0.9 & 3.5 & -0.1 & 5.1 & 1.8 \\
\hline 10 & 7.9 & 2.6 & 11.5 & 2.9 & 7.9 & 0.1 & 3.3 & 1.9 \\
\hline 11 & 10.0 & 0.5 & 10.3 & 2.9 & 8.6 & 0.6 & 8.5 & 2.4 \\
\hline 12 & 1.9 & 0.0 & 8.1 & 1.5 & 10.9 & 1.5 & 6.6 & 2.7 \\
\hline 13 & 10.7 & 0.7 & 0.0 & 0.0 & 11.5 & 1.1 & 0.0 & 0.0 \\
\hline 14 & 0.0 & 0.0 & 0.0 & -0.6 & 9.2 & 0.5 & 2.2 & 1.8 \\
\hline 15 & 0.0 & 0.0 & 3.0 & 0.5 & 10.8 & 0.7 & 7.0 & 2.4 \\
\hline 16 & 7.1 & 0.5 & 1.3 & -1.1 & 10.2 & 0.4 & 3.1 & 2.2 \\
\hline 17 & 0.0 & 0.0 & 12.3 & 2.4 & 9.0 & 0.9 & 7.6 & 2.6 \\
\hline 18 & 4.9 & -0.2 & 8.7 & 0.5 & 11.1 & 0.5 & 2.1 & 0.9 \\
\hline 19 & 3.9 & -0.5 & 13.6 & 1.5 & 11.1 & 0.9 & 5.9 & 1.4 \\
\hline 20 & 11.0 & 0.8 & 10.2 & 1.4 & 11.0 & 0.9 & 2.7 & 1.4 \\
\hline 21 & 6.5 & 0.5 & 12.9 & , 1.0 & 10.9 & 0.8 & 8.4 & 2.4 \\
\hline 22 & 4.5 & 1.2 & 13.0 & 1.4 & 10.7 & 0.9 & 7.2 & 1.7 \\
\hline 23 & 5.6 & 0.8 & 0.1 & -0.1 & 9.4 & 0.7 & 0.0 & 0.0 \\
\hline 24 & 6.9 & 0.7 & 12.6 & 1.4 & 6.2 & 1.2 & 0.0 & 0.0 \\
\hline 25 & 9.4 & 0.4 & 11.0 & 0.9 & 8.0 & 0.5 & 8.3 & 1.6 \\
\hline 26 & 4.0 & 0.3 & 13.1 & 1.5 & 9.7 & 0.4 & 5.5 & 1.0 \\
\hline 27 & 8.7 & -0.5 & 12.0 & 1.3 & 6.2 & 0.7 & 2.7 & 0.2 \\
\hline 28 & 9.7 & 2.1 & 13.0 & 1.3 & 7.3 & 0.8 & 6.9 & 1.1 \\
\hline 29 & 8.5 & 0.2 & 5.4 & -1.7 & 6.1 & 0.0 & 0.2 & 0.2 \\
\hline 30 & trace & -0.1 & 7.9 & 0.2 & 5.2 & -0.5 & 2.7 & 1.6 \\
\hline 31 & 7.5 & -0.8 & & & & & 0.1 & 0.1 \\
\hline Sums & 165.8 & 8.2 & 242.3 & 21.0 & 266.9 & 15.9 & 133.4 & 40.4 \\
\hline Means & 5.7 & 0.3 & 8.1 & 0.7 & 8.9 & 0.5 & 4.3 & $\begin{array}{r}70.7 \\
1.3\end{array}$ \\
\hline
\end{tabular}


I TABLe 3. Daily course of sunshine duration at Blue Hill, Milton, Mass., in hours per month. (See fig. 4.)

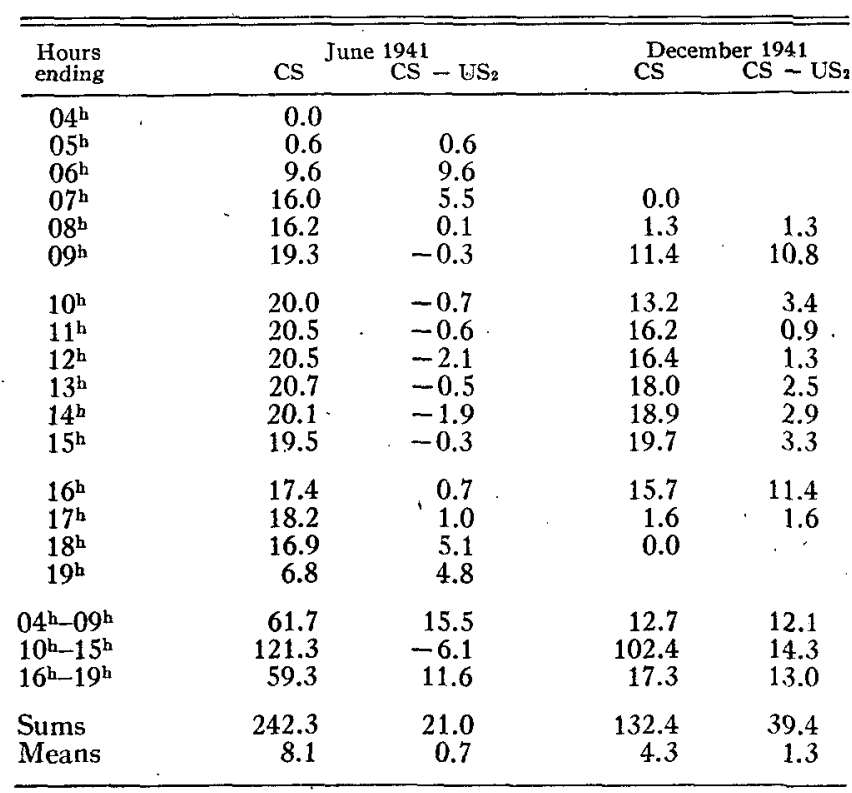

greater early and late in the day than at midday and greater in winter than in summer. These relationships are shown by the curves in fig. 4 .

A tabulation was made of the time of starting and stopping of the CS and $\mathrm{US}_{2}$ recorders with regard to sunrise and sunset (table 4). As it was desired to find the limits of the instruments under best conditions, the shortest three intervals for June and for December were selected and averaged.

Table 4 shows that the lower temperatures and lower angular elevations of the sun in December are not an important control in delaying registration of sunshine. These effects are overbalanced by the clearness of the dry air at Blue Hill, which rises above the smoky inversions of strong anticyclones in winter, and by the relative nearness of the sun to the earth in winter, when the intensity of sunlight, is 6-7 per cent greater than in June. Consequently, the smaller values, representing the brighter sunrise and sunset periods, occur in winter. The effect of afternoon convectional

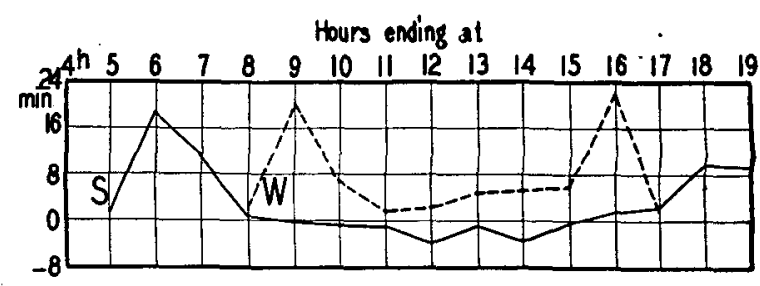

FIG. 4. Diurnal course of CS - US 2 at Blue Hill: (W) December and (S) June, 1941.

period of 7 years. The shortest interval between sunrise and starting time varied from $25 \mathrm{~min}$ in the Orkney Islands to $14 \mathrm{~min}$ in Jersey, while the shortest interval between ending time and sunset was $20 \mathrm{~min}$ and 10 min, respectively, at the sáme stations, with intermediate values at intermediate stations. February had more minima than any other month, though some occurred in summer (see also Neuberger, 1945).

Dr. W. Gorczynski has called our attention to similar measurements made in Manila by Selga (1928), who writes:

For a period of time, sufficiently long on very clear days, the difference has been observed and recorded between the astronomical sunrise and sunset on the one hand and the moment when the sun began or ceased to act on the [CS] card on the other hand.

The sum of the morning and evening differences is: winter, $0.5 \mathrm{hr}$; spring, $0.8 \mathrm{hr}$; summer, $1.6 \mathrm{hr}$; autumn, $0.9 \mathrm{hr}$.

Comparing these figures with those for Blue Hill and Great Britain, we find a fairly close similarity (table 5). Manila's excessive dampness probably explains its larger figure for summer.

The durations of the CS and $\mathrm{US}_{2}$ records for June and December, 1941, at Blue Hill are further compared in table 6. It will be noticed that the sum of the morning and evening differences in starting and ending times is greater than the difference in daily duration between the two records, especially in summer. This may be explained by the greater number and length of interruptions in the CS record.

To compare the radiation intensities at which the $\mathrm{CS}$ and $\mathrm{US}_{2}$ begin and cease to register, morning and

TABLE 4. Time after sunrise or before sunset when sunshine recorders at Blue Hill, Milton, Mass., started and stopped, averaged for shortest three intervals.

\begin{tabular}{clrrrr}
\hline Instrument & Month, 1941 & Started after sunrise & Stopped before sunset & Sum \\
\hline CS & June & $28 \mathrm{~min}=0.5 \mathrm{hr}$ & $45 \mathrm{~min}=0.7 \mathrm{hr}$ & $73 \mathrm{~min}=1.2 \mathrm{hr}$ \\
& December & $22 \mathrm{~min}=0.4 \mathrm{hr}$ & $12 \mathrm{~min}=\mathbf{0 . 2 \mathrm { hr }}$. & $34 \mathrm{~min}=0.6 \mathrm{hr}$ \\
$\mathrm{US}_{2}$ & June & $104 \mathrm{~min}=1.7 \mathrm{hr}$ & $73 \mathrm{~min}=1.2 \mathrm{hr}$ & $177 \mathrm{~min}=2.9 \mathrm{hr}$ \\
& December & $82 \mathrm{~min}=1.4 \mathrm{hr}$ & $\mathbf{5 4} \mathrm{min}=0.9 \mathrm{hr}$ &. & $136 \mathrm{~min}=2.3 \mathrm{hr}$
\end{tabular}

haze in causing earlier termination of the record on the clearest summer days is more marked for the CS than for the US, apparently because with the.US this effect is partly balanced by increased diffuse insolation, to which the US responds and the CS does not.

Curtis (1909) presents like figures for CS in Great Britain, selecting several of the lowest values over a
TABle 5. Morning plus evening minimum duration (in hours) . of dim sunshine on clear days (CS).

\begin{tabular}{lcc}
\hline \multicolumn{1}{c}{ Station } & Winter & Summer \\
\hline Orkney Islands & 0.6 & \\
Geldeston, Norfolk & 0.5 \\
Jersey & 0.4 & \\
Blue Hill, Milton, Mass. & 0.6 & 1.2 \\
Manila, P: I. & $\mathbf{0 . 5}$ & 1.6 \\
\hline
\end{tabular}


TABLE 6. Average differences in times of starting and ending, daily number of interruptions, and duration, CS versus $U_{2}$, at Blue Hill, Milton, Mass.

\begin{tabular}{|c|c|c|c|c|c|c|c|c|c|c|}
\hline \multirow[t]{2}{*}{$\begin{array}{c}\text { Month } \\
1941\end{array}$} & \multicolumn{2}{|c|}{$\begin{array}{l}\text { Starting time } \\
\text { CS before US }\end{array}$} & \multicolumn{2}{|c|}{$\begin{array}{l}\text { Ending time } \\
\text { CS after US }\end{array}$} & \multirow{2}{*}{$\begin{array}{l}\text { Sum } \\
\text { hr }\end{array}$} & \multirow{2}{*}{\multicolumn{2}{|c|}{$\begin{array}{l}\text { Daily number of } \\
\text { interruptions to record } \\
\mathrm{CS}\end{array}$}} & \multicolumn{2}{|c|}{ Average daily duration } & \multirow{2}{*}{$\begin{array}{c}\text { Difference } \\
\text { CS - US } \\
\text { hrr }\end{array}$} \\
\hline & $\min$ & hrr & $\min$ & $\mathrm{hr}$ & & & & hr. & hr & \\
\hline December & 66 & 1.1 & 44 & 0.7 & 1.8 & 3.0 & 1.8 & 4.3 & 3.0 & 1.3 \\
\hline June & 52 & 0.9 & 47 & 0.8 & 1.7 & 4.0 & 1.5 & 8.1 & 7.4 & 0.7 \\
\hline
\end{tabular}

TABLE 7. Insolation on a horizontal surface, in $\mathrm{cal} \mathrm{cm}^{-2} \mathrm{~min}^{-1}$, measured by pyrheliometers at times when records of sunshine duration start and stop at Blue Hill, Milton, Mass. The values in brackets are not significant for that type of instrument.

\begin{tabular}{|c|c|c|c|c|c|c|c|c|c|}
\hline \multirow[b]{3}{*}{$\begin{array}{l}\text { Direct insolation at } \\
\text { normal incidence }\end{array}$} & \multirow{3}{*}{$\frac{\begin{array}{c}\text { Month } \\
1941\end{array}}{\left\{\begin{array}{l}\text { December } \\
\text { June } \\
\text { Average }\end{array}\right.}$} & \multicolumn{6}{|c|}{ Monthly average * } & \multirow{2}{*}{\multicolumn{2}{|c|}{$\begin{array}{c}\text { Average for } 3 \text { clearest } \\
\text { mornings and } 3 \\
\text { clearest evenings } \\
\text { CS US }\end{array}$}} \\
\hline & & \multicolumn{2}{|c|}{$\underset{\text { CS }}{\text { Early morning }}$ US } & \multicolumn{2}{|c|}{$\begin{array}{l}\text { Late afternoon } \\
\text { CS }\end{array}$} & \multicolumn{2}{|c|}{ CS Average us } & & \\
\hline & & $\begin{array}{l}0.33 \\
0.31 \\
0.32\end{array}$ & $\begin{array}{l}{[0.83]} \\
{[0.71]} \\
{[0.77]}\end{array}$ & $\begin{array}{l}0.39 \\
0.30 \\
0.34\end{array}$ & $\begin{array}{l}{[0.81]} \\
{[0.54]} \\
{[0.68]}\end{array}$ & $\begin{array}{l}0.36 \\
0.30 \\
0.33\end{array}$ & $\begin{array}{l}{[0.82]} \\
{[0.62]} \\
{[0.72]}\end{array}$ & $\begin{array}{l}0.34 \\
0.27 \\
0.30\end{array}$ & $\begin{array}{l}{[0.73]} \\
{[0.32]} \\
{[0.52]}\end{array}$ \\
\hline $\begin{array}{l}\text { Total insolation on a } \\
\text { horizontal surface }\end{array}$ & $\left\{\begin{array}{l}\text { December } \\
\text { June } \\
\text { Average }\end{array}\right.$ & $\begin{array}{l}{[0.17]} \\
{[0.30]} \\
{[0.24]}\end{array}$ & $\begin{array}{l}0.37 \\
0.50 \\
0.48\end{array}$ & $\begin{array}{l}{[0.11]} \\
{[0.18]} \\
{[0.14]}\end{array}$ & $\begin{array}{l}0.27 \\
0.36 \\
0.32\end{array}$ & $\begin{array}{l}{[0.14]} \\
{[0.24]} \\
{[0.19]}\end{array}$ & $\begin{array}{l}0.32 \\
0.43 \\
0.37\end{array}$ & $\begin{array}{l}{[0.05]} \\
{[0.06]} \\
{[0.06]}\end{array}$ & $\begin{array}{l}0.23 \\
0.26 \\
0.24\end{array}$ \\
\hline
\end{tabular}

* Based on 11-23 cases each for normal incidence and 23-27 each for horizontal surface.

afternoon, these times of starting and stopping were tabulated for each day. Then the readings of the Blue Hill pyrheliometers, which record total insolation on a horizontal surface and direct insolation at normal incidence, were noted at those moments (see table 7). The CS is affected only by direct insolation at normal incidence. Its record is therefore more comparable with the record of direct solar radiation. The record of the $\mathrm{US}_{2}$, on the other hand, may more properly be compared with that of total insolation, though the US recorder is not horizontal but is tipped toward the south.

The number of cases in table 7 is smaller for the direct than for the total radiation in the morning, because the tube could not be turned on in time to catch the initial values in some instances, while the pyrheliometer for total radiation ran constantly.

These values (first four columns of table 7) represent average conditions, but do not show the limiting values for the sunshine recorders accurately. Obviously, if the sunshine starts or stops suddenly, the curve of the potentiometer record is so steep that the critical value for the sunshine recorder cannot easily be determined. The US has a lag of perhaps $3 \mathrm{~min}$; the CS, less. ${ }^{3}$ To eliminate lag and possible small time errors, critical values were calculated by adding the starting and ending values and dividing by two. To estimate the limits of the two sunshine recorders, the shortest three morning and evening intervals for June and December were selected, because these examples furnish the clearest air and smoothest curves on the pyrheliometer (see last two columns of table 7).

The significant values for the CS are those of direct insolation; for the US, total insolation. Possibly the fact that the CS operates with a smaller value in June

${ }^{3}$ There is no real lag with CS, but a strong burn spreads enough to overlap a few minutes beyond its time space on the card. than in December is a temperature effect; or it may be a chance variation, for the US shows an opposite difference. The limiting value, however, is reached farther from sunrise and sunset in June than in December, probably because the air is more absorptive in June and the sunlight is 6 or 7 per cent less intense.

The direct, normal-incidence insolation exceeds the total at the beginning and end of the day, while at noon the total can exceed the direct. This parallels the differences observed in the performance of the CS and US recorders.

The US registers occasionally at midday when no direct radiation is shown even by the normal-incidence pyrheliometer. For example, on 14 June the $\mathrm{US}_{2}$ registered $0.6 \mathrm{hr}$ 'sunshine' between $13^{\mathrm{h}} 11^{\mathrm{m}}$ and $14^{\mathrm{h}} 13^{\mathrm{m}}$. The total radiation rose briefly to $0.9 \mathrm{cal} \mathrm{cm}^{-2} \mathrm{~min}^{-1}$ at $12^{\mathrm{h}} 23^{\mathrm{m}}$ and again to 0.8 at $13^{\mathrm{h}} 10^{\mathrm{m}}$. This was sufficient to start the US recorder. The radiation reached a maximum of $1.2 \mathrm{cal} \mathrm{cm}^{-2} \mathrm{~min}^{-1}$ at $13^{\mathrm{h}} 45^{\mathrm{m}}$ and fell below 0.7 after $14^{\mathrm{h}}$, and the US record soon ended. These radiation values are well above the more precisely determined minima for clear mornings and evenings. The CS record, of course, was blank for this period, which illustrates how the US can register more than the CS at midday in summer. This is an advantage of the US, for intense diffuse insolation is as important meteorologically as the equivalent amount of direct sunshine.

\section{Low-sun corrections}

It has been shown that the CS record exceeded the uncorrected $\mathrm{US}_{2}$ record by about 0.8 hour per day or 15 per cent at Blue Hill for an annual average. Unfortunately, the instrument difference, CS - US, cannot be assumed with certainty, because we have so few direct comparisons and these show variations in level for US (see fig. 1). 
TABLE 8. Monthly and annual averages of daily low-sun correction added to records of US sunshine recorder at U. S. Weather Bureau stations, annual average daily sunshine duration (instrumental record + LSC), and ratio of the low-sun correction to the sunshine duration (both annual averages)

\begin{tabular}{|c|c|c|c|c|c|c|c|c|c|c|c|c|c|c|c|c|}
\hline \multirow[b]{2}{*}{ Station } & \multirow[b]{2}{*}{ Years } & \multicolumn{13}{|c|}{ Low-sun correction (LSC) } & \multirow[b]{2}{*}{$\begin{array}{c}\text { Dura- } \\
\text { tionf } \\
\text { hr }\end{array}$} & \multirow[b]{2}{*}{$\begin{array}{l}\text { LSC/Dur. } \\
\text { per cent }\end{array}$} \\
\hline & & $\begin{array}{c}\text { Jan. } \\
\text { hr }\end{array}$ & $\begin{array}{c}\text { Feb. } \\
\text { hr }\end{array}$ & $\begin{array}{c}\text { March } \\
\mathrm{hr}\end{array}$ & $\begin{array}{c}\text { April } \\
\mathrm{hr}\end{array}$ & $\begin{array}{c}\text { May } \\
\text { hir }\end{array}$ & $\begin{array}{c}\text { June } \\
\text { hr }\end{array}$ & $\underset{\mathrm{hr}}{\mathrm{July}}$ & $\begin{array}{c}\text { Aug. } \\
\mathrm{hr}\end{array}$ & $\begin{array}{c}\text { Sept. } \\
\mathrm{hr}\end{array}$ & $\begin{array}{c}\text { Oct. } \\
\text { hr }\end{array}$ & $\begin{array}{c}\text { Nov. } \\
\text { hr }\end{array}$ & $\begin{array}{c}\text { Dec. } \\
\text { hr }\end{array}$ & $\underset{\mathrm{hr}}{\text { Annual }}$ & & \\
\hline \multicolumn{17}{|c|}{ a. Northern and cool western stations } \\
\hline Boston, Mass. & $1919-20$ & 0.7 & 0.8 & 0.9 & 0.7 & 0.8 & 0.9 & 1.0 & 0.7 & 0.6 & 0.6 & 0.7 & 0.7 & 0.8 & $(7.2)$ & 11 \\
\hline [Boston* & $1930-35$ & 1.1 & 1.3 & 1.4 & 1.7 & 1.8 & 1.7 & 2.0 & 2.1 & 1.7 & 1.3 & 1.2 & 1.0 & 1.5 & 7.0 & 21] \\
\hline Boston airport & $1936-43$ & -0.8 & 0.6 & 0.7 & 0.7 & 0.7 & 0.7 & 0.8 & 0.9 & 0.9 & 0.8 & 0.7 & 0.6 & 0.7 & $(6.9)$ & 10 \\
\hline Burlington, Vt. & 1939 & 0.5 & 0.2 & 0.5 & 0.4 & 0.7 & 0.5 & 0.7 & 0.8 & 0.7 & 0.5 & 0.7 & 0.2 & 0.5 & 5.6 & 9 \\
\hline Buffalo, N. Y. & 1939 & 0.1 & 0.3 & 0.3 & 0.4 & 1.1 & 0.8 & 1.0 & 1.0 & 0.4 & 0.8 & 0.4 & 0.1 & 0.6 & 6.2 & 10 \\
\hline Cincinnati, Ohio & 1939 & 0.3 & 0.6 & 0.8 & 1.1 & 1.6 & 1.2 & 1.3 & 1.9 & 0.7 & 0.5 & 0.7 & 0.6 & 0.9 & 7.4 & 12 \\
\hline Chicago, IIl. - & $1939-40$ & 0.6 & 0.7 & 0.8 & 1.2 & 1.6 & 1.8 & 2.1 & 1.0 & 1.4 & 1.1 & 0.6 & 0.5 & 1.1 & 7.2 & 15 \\
\hline Duluth, Minn. & 1939 & 0.2 & 0.6 & 0.6 & 0.5 & 0.9 & 0.8 & 1.5 & 1.2 & 0.5 & 0.4 & 0.7 & 0.6 & 0.7 & 6.8 & 10 \\
\hline Bismarck, N. Dak. & $1939-43$ & 0.3 & 0.4 & 0.4 & 0.5 & 0.6 & 1.2 & 1.0 & 1.0 & 0.8 & 0.5 & 0.5 & 0.5 & 0.6 & 7.4 & 8 \\
\hline Havre, Mont. & $1939-43$ & 0.4 & 0.3 & 0.4 & 0.4 & 0.5 & 0.6 & 0.8 & 0.6 & 0.4 & 0.4 & 0.3 & 0.4 & 0.5 & 7.4 & 7 \\
\hline Boise, Idaho & 1939 & 0.3 & 0.7 & 1.0 & 1.5 & 1.7 & 2.0 & 2.2 & 2.3 & 2.0 & 1.2 & 1.1 & 0.4 & 1.4 & 8.2 & 16 \\
\hline Seattle, Wash. & $1939-43$ & 0.1 & 0.3 & 0.4 & 0.5 & 0.7 & 1.0 & 1.2 & 1.1 & 0.2 & 0.4 & 0.1 & 0.3 & 0.6 & 5.6 & 11 \\
\hline San Francisco, Calif. $\dagger$ & 19.36 & 0.7 & 0.6 & 1.4 & 1.3 & 1.0 & 0.7 & 0.8 & 0.3 & 0.4 & 0.4 & 0.5 & 0.3 & 0.7 & 8.0 & 9 \\
\hline \multirow[t]{2}{*}{ Average } & & 0.5 & 0.6 & 0.7 & 0.8 & 1.1 & 1.1 & 1.3 & 1.1 & 0.9 & 0.7 & 0.6 & 0.5 & 0.8 & 7.0 & 11 \\
\hline & & \multicolumn{13}{|c|}{ b. Southern stations } & & \\
\hline Wilmington, Del. & 1939 & 0.8 & 1.0 & 1.3 & 0.9 & 1.2 & 1.0 & 1.2 & 0.8 & 0.8 & 1.2 & 1.2 & 1.0 & 1.0 & 7.9 & 13 \\
\hline Miami, Fla.t & 1936 & 1.7 & 1.1 & 1.6 & 1.8 & 1.4 & 1.1 & 1.4 & 1.0 & 1.0 & 0.9 & 1.2 & 1.8 & 1.3 & 8.1 & 16 \\
\hline Atlanta, Ga. & $1939-43$ & 1.0 & 0.9 & 1.0 & 1.4 & 1.6 & 1.3 & 1.1 & 1.4 & 1.6 & 1.2 & 1.1 & 0.8 & 1.2 & 7.4 & 16 \\
\hline Little Rock, Ark. & $1939-41$ & 1.1 & 0.7 & 1.2 & 1.1 & 1.6 & 1.2 & 1.5 & 1.5 & 1.7 & 1.6 & 1.6 & 1.0 & 1.3 & 7.5 & 17 \\
\hline Phoenix, Ariz. $\dagger$ & 19.36 & 0.9 & 0.5 & 1.1 & 1.1 & 1.3 & 1.3 & 1.0 & 0.9 & 1.1 & 1.2 & 0.6 & 0.6 & 1.0 & 10.3 & 10 \\
\hline Yuma, Ariz. & 1936 & 1.4 & 1.2 & 1.5 & 1.7 & 1.9 & 1.9 & 1.3 & 1.3 & 2.0 & 1.5 & 1.0 & 1.0 & 1.5 & 11.0 & 14 \\
\hline San Diego, Calif. $†$ & 1936 & 0.9 & 0.8 & $1: 0$ & 1.1 & 1.9 & 1.9 & 1.0 & 0.7 & 1.2 & 1.1 & 1.3 & 1.0 & 1.2 & 8.2 & 15 \\
\hline Los Angeles, Calif. $†$ & 1936 & 0.8 & 0.8 & 1.5 & 0.8 & 1.7 & 1.5 & 1.7 & 1.6 & 1.5 & 1.4 & 1.5 & 0.7 & 1.3 & 8.2 & 16 \\
\hline Fresno, Calif. $\dagger$ & 19.36 & 0.8 & 0.9 & 1.3 & 1.4 & 1.7 & 1.3 & 1.3 & 1.3 & 1.6 & 1.5 & 1.6 & 0.6 & 1.3 & 9.8 & 13 \\
\hline Average & & 1.0 & 0.9 & 1.3 & 1.3 & 1.6 & 1.4 & 1.3 & 1.2 & 1.4 & 1.3 & 1.2 & 0.9 & 1.2 & 8.7 & 14 \\
\hline
\end{tabular}

* Boston locations various in this period: Values not used in averages.

+ Gorczynski, 1945 , p. 136.

$\ddagger$ From Bulletin W' U. S. Weather Bureau, 1930 ed.

The instrument difference is more or less balanced by the Weather Bureau practice of adding 'low-sun,' incorrectly called 'twilight,' 'corrections' to the US records. The observer notes the length of time the sun shone before and after the recorded duration and adds this to the record. The low-sun correction (hereafter abbreviated 'LSC') varies in general with the sunshine duration-the more sun, the more low sun. Thus, the astronomical control over LSC's is less important than the meteorological. LSC is generally greater in summer than in winter and in southern locations than in the north, because, when it is cloudy in the mornings or evenings, there is no low-angle sunshine and, therefore, no LSC. Northern stations show the larger seasonal variation. Some southern stations have a secondary minimum in summer, the season of greatest cloudiness there. Foggy mornings or evenings decrease LSC's, as is well shown at San Francisco. For spring in 1936, LSC was $1.2 \mathrm{hr}$, for summer, the foggy season, $0.6 \mathrm{hr}$.

LSC is greater in large cities, where the smoke reduces the sunlight and shortehs the record at each end (see Chicago and Boston, table 8). Soot on the US tube has a similar effect, or tall buildings may shut off part of the sunlight and necessitate a larger LSC. Many of our older records are from smoky cities; the recent tendency has been to move weather stations out to less smoky airports.
The values for Boston illustrate some of these changes. The annual LSC 1919-1920 was $0.8 \mathrm{hr}$. Later the city may have become more smoky. In 1930 the station was moved for 3 years to temporary quarters in a low building. The LSC for this period rose to 1.7 $h r$, quite out of line with other northern cities. Next the US recorder'was on the Weather Bureau's new office at the top of the Federal Building, LSC $1.1 \mathrm{hr}$. Since 1935 the US has been at the Boston Airport, LSC $0.7 \mathrm{hr}$. The effect of these changing low-sun corrections has been to make the record more homogeneous than it would have been otherwise.

Table 8 shows typical LSC's for various stations, computed from data furnished by the Central Office of the U.S. Weather Bureau. Table 8 also compares the amount of these LSC's with the published annual average sunshine duration.

\section{Conversion values from instrument comparisons}

Published values for the US recorder are always corrected for dim low sun. To make them comparable with CS records one should, therefore, subtract the appropriate LSC to obtain the value for bright sunshine only. This should then be increased by the amount which represents the instrument difference (CS - US). 
TABle 9. Cloudiness, daytime hours, 1942.

\begin{tabular}{lccccccccccccc}
\hline & Jan. & Feb. & March & April & May & June & July & Aug. & Sept. & Oct. & Nov. & Dec. & Year \\
\hline Blue Hill & 5.5 & 5.5 & 7.2 & 6.0 & 7.2 & 6.7 & 6.8 & 5.5 & 5.2 & 5.6 & 6.1 & 6.3 & 6.1 \\
Boston & 5.6 & 5.2 & 6.8 & 6.0 & 7.2 & 6.7 & 6.8 & 5.7 & 5.4 & 5.6 & 6.4 & 6.3 & 6.1 \\
\hline
\end{tabular}

For example, during the 6 years 1930-1935 the daily duration of bright sunshine averaged $6.2 \mathrm{hr}$ at Blue Hill, and that of all sunshine averaged $7.0 \mathrm{hr}$ at Boston. The average LSC at Boston for this period was $1.5 \mathrm{hr}$, therefore $7.0 \mathrm{hr}-1.5 \mathrm{hr}=5.5 \mathrm{hr}=$ the uncorrected value of bright insolation for the US at Boston. Adding $0.8 \mathrm{hr}$, the instrument difference, $\mathrm{CS}-\mathrm{US}_{2}$, we get $6.3 \mathrm{hr}$, a figure for Boston comparable with the CS record of $6.2 \mathrm{hr}$ at Blue Hill. The net conversion value is $0.7 \mathrm{hr}$; and bright sunshine duration at the two stations for this period is virtually the same. This result appears reasonable, for the astronomical difference between Boston and Blue Hill is negligible and the cloudiness almost identical, as is illustrated in table 9.

Massachusetts Institute of Technology, Cambridge, just across the Charles River from Boston, kept a record of total radiation on a horizontal surface (19401942). Comparison of samples of this record with the Blue Hill record for the same period shows a close similarity, further justifying the assumption that the two locations have about the same sunshine (table 10).

Table 10. Blue Hill and Cambridge, Mass., compared as to duration of bright sunshine and amount of total insolation.

\begin{tabular}{|c|c|c|c|c|}
\hline \multirow[b]{2}{*}{. } & \multicolumn{2}{|c|}{$\begin{array}{l}\text { Average daily duration } \\
\text { of bright sunshine } \\
\left(>20 \mathrm{cal} \mathrm{cm}^{-2} \mathrm{hr}^{-1}\right)\end{array}$} & \multicolumn{2}{|c|}{$\begin{array}{l}\text { Average daily total } \\
\text { insolation on hori- } \\
\text { zontal surface }\end{array}$} \\
\hline & $\begin{array}{l}\text { Blue } \\
\text { Hill } \\
\mathrm{hr}\end{array}$ & $\begin{array}{l}\text { Cam- } \\
\text { bridge } \\
\text { hr }\end{array}$ & $\begin{array}{l}\text { Blue } \\
\text { Hill } \\
\text { cal } \mathrm{cm}^{-2}\end{array}$ & $\begin{array}{c}\text { Cam- } \\
\text { bridge } \\
\text { cal } \mathrm{cm}^{-2}\end{array}$ \\
\hline $\begin{array}{l}\text { Jan.: 1941, } 1942 \\
\text { June, July: } 1941\end{array}$ & $\begin{array}{l}3.3 \\
8.8\end{array}$ & $\begin{array}{l}3.4 \\
8.4\end{array}$ & $\begin{array}{l}146.5 \\
497.5\end{array}$ & $\begin{array}{l}150.0 \\
492.0\end{array}$ \\
\hline Mean of 15 weeks & 5.8 & 5.8 & 322.0 & 321.0 \\
\hline
\end{tabular}

A further check shows that our conversion values do not give consistent results. For instance, during the 3 years 1936-1938 the low-sun correction for Boston airport (East Boston) averaged $0.8 \mathrm{hr}$, which just balanced the assumed instrument difference, also 0.8 $\mathrm{hr}$; therefore, the published values, $6.8 \mathrm{hr}$ for Boston airport and $5.9 \mathrm{hr}$ for Blue Hill, should indicate that Boston had $0.9 \mathrm{hr}$ more sunshine than Blue Hill. So large a difference in sunshine duration seems quite unlikely.

Moreover, for the 30-year period (1901-1930) the annual daily difference between the US + LSC at Boston and the CS at Blue Hill averaged $1.0 \mathrm{hr}$, which also is probably close to the low-sun correction for those years and would imply no average annual instrument difference if we assume equal sunshine. This can be true because the US is likely to register more than the CS in summer and less in winter. Our Blue Hill $\mathrm{US}_{2}$, which was adjusted with particular care to meet the Weather Bureau standard, seems to have registered somewhat lower than most station instruments in general use, equaling $\mathrm{CS}$ only in midsummer and registering much lower than $\mathrm{CS}$ in winter. Our Blue Hill $\mathrm{US}_{1}$, an older instrument, read much higher than $\mathrm{US}_{2}$ (annual average of $1 \mathrm{hr}$ daily or 17 per cent, fig. 3). Fig. 3 shows curves for CS (Blue Hill) minus US (Boston) as recorded in 1940, in 1941, and in 19401943 combined. In the combined period several different instruments were in use, so that the seasonal trend is obscured. The variation in level of the US instrument makes the establishment of conversion values difficult. Conversion values for a group of 11 northern stations and a group of 9 southern stations in the United States are presented tentatively in table 11 and in fig. 6 .

We have used an average of $\mathrm{US}_{1}$ and $\mathrm{US}_{2}$ in computing the instrument difference. These figures obtained at Blue Hill are appropriate for the north. It is likely that the winter difference CS - US would be less in the south. The LSC is typically a greater, and the recorder difference (CS - US) a smaller, value in summer than in winter. Consequently, the conversion values, which equal the difference between these two, show a still more marked seasonal variation (see fig. 6).

\section{Conversion values from comparisons of long records}

A second, and perhaps more practicable, method of obtaining conversion values is through direct

TABLE 11. Conversion values in hours, relating CS and US. Add the conversion to CS to convert to US; subtract from US to convert to CS.

\begin{tabular}{|c|c|c|c|c|c|c|c|c|c|c|c|c|c|}
\hline & Jan. & Feb. & March & April & May & June & July & Aug. & Sept. & Oct. & Nov. & Dec. & Year \\
\hline \multicolumn{14}{|c|}{ Northern United States } \\
\hline LSC (11 stations, from table 9 ) & 0.5 & 0.6 & 0.7 & 0.8 & 1.1 & 1.1 & 1.3 & 1.1 & 0.9 & 0.7 & 0.6 & 0.5 & 0.8 \\
\hline CS - $\frac{1}{2}\left(\mathrm{US}_{1}+\mathrm{US}_{2}\right)$ (Blue Hili) & 0.8 & 0.4 & 0.1 & 0.0 & -0.1 & -0.2 & -0.8 & -0.1 & -0.1 & 0.6 & 0.9 & 0.8 & 0.2 \\
\hline Conversion values & -0.3 & 0.2 & 0.6 & 0.8 & 1.2 & 1.3 & 2.1 & 1.2 & 1.0 & 0.1 & -0.3 & -0.3 & 0.6 \\
\hline \multicolumn{14}{|c|}{ Southern United States } \\
\hline LSC (9 sta ions, from table 9 ) & 1.0 & 0.9 & 1.3 & 1.3 & 1.6 & 1.4 & 1.3 & 1.2 & 1.4 & 1.3 & 1.2 & 0.9 & 1.2 \\
\hline$C S-\frac{1}{2}\left(U_{1}+U_{2}\right)$ (Blue Hill $)$ & 0.8 & 0.4 & 0.1 & 0.0 & -0.1 & -0.2 & -0.8 & -0.1 & -0.1 & 0.6 & 0.9 & 0.8 & 0.2 \\
\hline Conversion values & 0.2 & 0.5 & 1.2 & 1.3 & 1.7 & 1.6 & 2.1 & 1.3 & 1.5 & 0.7 & 0.3 & 0.1 & 1.0 \\
\hline
\end{tabular}


TABLE 12. Difference in sunshine duration, LSC + US - CS, between adjacent stations, in hours.

\begin{tabular}{|c|c|c|c|c|c|c|c|c|c|c|c|c|c|c|c|c|}
\hline Stations & $\begin{array}{c}\text { Separa- } \\
\text { tion } \\
\text { miles }\end{array}$ & $\begin{array}{l}\text { Vears of } \\
\text { record }\end{array}$ & $\begin{array}{l}\text { Length } \\
\text { of record } \\
\text { years }\end{array}$ & Jan. & Feb. & March & April & May & June & July & Aug. & Sept. & Oct. & Nov. & Dec. & Year \\
\hline \multicolumn{17}{|c|}{ Selected near-by pairs of United States and Canadian stations } \\
\hline $\begin{array}{l}\text { Eastport, Me. } \\
\text { St. John, N. B. }\end{array}$ & 45 & $\begin{array}{l}1893-1930 \\
1916-1931\end{array}$ & $\begin{array}{l}37 \\
15\end{array}$ & 0.3 & 0.9 & 1.2 & 1.6 & 1.0 & 1.7 & 2.0 & 1.4 & 1.2 & 0.8 & 0.0 & 0.3 & 1.0 \\
\hline $\begin{array}{l}\text { Burlington, Vt. } \\
\text { Montreal, P. Q. }\end{array}$ & 80 & $\begin{array}{l}1905-1930 \\
1881-1931\end{array}$ & $\begin{array}{l}25 \\
50\end{array}$ & 0.6 & 1.0 & 0.9 & 0.6 & 0.8 & 1.4 & 1.1 & 0.6 & 0.3 & 0.4 & 0.1 & 0.1 & 0.6 \\
\hline $\begin{array}{l}\text { Canton, N. Y. } \\
\text { Ottawa, Ont. }\end{array}$ & 60 & $\begin{array}{l}1906-1930 \\
1898-1931\end{array}$ & $\begin{array}{l}24 \\
33\end{array}$ & 0.3 & 0.6 & 0.9 & $0 . \dot{2}$ & 0.5 & 1.3 & 0.9 & 0.5 & 0.6 & 0.2 & -0.1 & 0.1 & 0.5 \\
\hline $\begin{array}{l}\text { Buffalo, N. Y. } \\
\text { Toronto, Ont. }\end{array}$ & 60 & $\begin{array}{r}1910-1930 \\
1881-1931\end{array}$ & $\begin{array}{l}20 \\
50\end{array}$ & 0.4 & 0.3 & 1.1 & 0.5 & 1.2 & 1.1 & 0.8 & 0.3 & 0.3 & 0.3 & 0.2 & -0.2 & 0.5 \\
\hline $\begin{array}{l}\text { Seattle, Wash. } \\
\text { Vancouver, B. C. }\end{array}$ & 115 & $\begin{array}{l}1894-1930 \\
1908-1931\end{array}$ & $\begin{array}{l}36 \\
23\end{array}$ & 0.6 & 0.8 & 1.0 & 1.1 & 0.4 & 1.3 & 0.7 & -0.4 & 0.2 & 0.1 & 0.2 & 0.5 & 0.6 \\
\hline \multicolumn{2}{|c|}{ Average of 5 pairs above, $(A)$} & & $\cdots$ & 0.4 & 0.7 & 1.0 & 0.8 & 0.8 & 1.4 & 1.1 & 0.5 & 0.5 & 0.4 & 0.1 & 0.2 & 0.65 \\
\hline $\begin{array}{l}\text { Boston } \\
\text { Blue Hill }\end{array}$ & 10 & & $\begin{array}{l}37 \\
60\end{array}$ & 0.5 & 1.0 & 1.4 & 1.3 & 1.4 & 1.8 & 1.5 & 1.1 & 1.3 & 0.6 & 0.2 & 0.4 & 1.0 \\
\hline General average, $\frac{1}{3}(2 A$ & $+B)$ & & & 0.4 & 0.8 & 1.1 & 1.0 & 1.0 & 1.5 & 1.2 & 0.7 & 0.8 & 0.5 & 0.1 & 0.3 & 0.8 \\
\hline \multicolumn{17}{|c|}{ Other pairs of United States and Canadian stations } \\
\hline $\begin{array}{l}\text { Minneapolis, Minn. } \\
\text { Winnipeg, Man. }\end{array}$ & 370 & & $\begin{array}{l}16 \\
50\end{array}$ & 1.3 & 0.7 & 1.4 & 0.8 & 0.9 & 1.2 & 1.2 & 1.1 & 0.9 & 1.3 & 0.9 & 1.0 & 1.1 \\
\hline $\begin{array}{l}\text { Bismarck, N. Dak. } \\
\text { Brandon, Man. }\end{array}$ & 180 & & $\begin{array}{l}37 \\
40\end{array}$ & 1.3 & 1.5 & 1.5 & 1.4 & 1.4 & 2.4 & 2.4 & 1.6 & 1.8 & 2.0 & 1.7 & -1.5 & 1.7 \\
\hline $\begin{array}{l}\text { Havre, Mont. } \\
\text { Medicine Hat, Alta. }\end{array}$ & 95 & & $\begin{array}{l}26 \\
25\end{array}$ & 1.4 & 1.5 & 1.8 & 1.0 & 0.9 & 1.2 & 1.2 & 1.0 & 1.1 & 0.5 & 0.7 & 1.0 & 1.1 \\
\hline $\begin{array}{l}\text { Helena, Mont. } \\
\text { Calgary, Alta. }\end{array}$ & 300 & & $\begin{array}{l}37 \\
10\end{array}$ & 0.3 & 0.4 & 1.6 & 1.9 & 0.6 & 2.2 & 2.0 & 2.3 & 1.5 & 0.7 & 0.3 & 0.2 & 1.2 \\
\hline $\begin{array}{l}\text { Spokane, Wash. } \\
\text { Nelson, B. C. }\end{array}$ & 120 & & $\begin{array}{l}33 \\
12\end{array}$ & 0.9 & 1.4 & 2.4 & 2.6 & 2.1 & 4.2 & 2.3 & 2.8 & 2.6 & 2.2 & 1.2 & 0.8 & 2.1 \\
\hline $\begin{array}{l}\text { Spokane, Wash. } \\
\text { Kamloops, B. C. }\end{array}$ & 250 & & $\begin{array}{l}33 \\
25\end{array}$ & 0.1 & 0.3 & 0.7 & 1.7 & 1.6 & 2.6 & 2.4 & 2.3 & 1.5 & 1.0 & 0.2 & 0.2 & 1.2 \\
\hline
\end{tabular}

comparison of long-term CS and US corrected records, from pairs of near-by stations. This method has the advantage of basing the comparison on many instruments rather than a few, although introducing errors from differences in climate (see Gorczynski, $1943 ; 1945)$.

Table 12 and fig. 6 present some long-record comparisons by months; data taken from Bulletin $W$, U. S. Weather Bureau, 1930 ed., and Köppen-Geiger Handbuch, Band 2, Teil J, 2 Lief., "Canada," by A. J. Connor (1938). The Canadian Meteorological Service kindly furnished information about the length of the Canadian records.

Out of the 11 pairs of Canadian and United States stations, 5 have been selected as best for obtaining an average (see fig. 5). Of the 6 not used, 4 are much farther apart than those in the first group, while 2 are about the same distance apart as the most widely separated pair in the preferred group. These two were not used in the general average because in the pair consisting of Havre and Medicine Hat the monthly distribution of values is so atypical and in the pair Spokane and Nelson the differences throughout are so large as to suggest a considerable real difference in sunshine duration.

To obtain a general average for (US - CS) longterm records we have introduced the Boston and Blue Hill record, arbitrarily giving it one half the weight of the average of the 5 United States and Canadian pairs: Boston and Blue Hill are much closer together than

TABle 13. Average daily duration of sunshine at Tacubaya, Mexico, in hours.

\begin{tabular}{|c|c|c|c|c|c|c|c|c|c|c|c|c|c|c|}
\hline & & Jan. & Feb. & March & Āpril & May & June & July & Aug. & Sept. & Oct. & Nov. & Dec. & Year \\
\hline $\begin{array}{l}\mathrm{LSC}+\mathrm{US} \\
\mathrm{CS} \\
\mathrm{LSC}+\mathrm{US}-\mathrm{CS}\end{array}$ & $\begin{array}{l}1921-30 \\
1909-21\end{array}$ & $\begin{array}{l}7.4 \\
6.2 \\
1.2\end{array}$ & $\begin{array}{l}8.1 \\
6.9 \\
1.2\end{array}$ & $\begin{array}{l}8.5 \\
6.3 \\
2.2\end{array}$ & $\begin{array}{l}8.0 \\
5.6 \\
2.4\end{array}$ & $\begin{array}{l}7.5 \\
5.7 \\
1.8\end{array}$ & $\begin{array}{l}6.9 \\
5.0 \\
1.9\end{array}$ & $\begin{array}{l}6.3 \\
5.2 \\
1.1\end{array}$ & $\begin{array}{l}6.6 \\
6.1 \\
0.5\end{array}$ & $\begin{array}{l}5.5 \\
4.9 \\
0.6\end{array}$ & $\begin{array}{l}6.4 \\
5.7 \\
0.7\end{array}$ & $\begin{array}{l}7.0 \\
6.2 \\
0.8\end{array}$ & $\begin{array}{l}7.2 \\
5.6 \\
1.6\end{array}$ & $\begin{array}{l}7.1 \\
5.8 \\
1.3\end{array}$ \\
\hline $\mathrm{LSC}+\mathrm{US}-\mathrm{CS}$ & & $\begin{array}{c}\text { Winter } \\
1.3\end{array}$ & & & $\begin{array}{c}\text { Spring } \\
2.1\end{array}$ & & & $\begin{array}{c}\text { Summer } \\
1.2\end{array}$ & & & $\underset{0.7}{A \text { utumn }}$ & & & \\
\hline
\end{tabular}



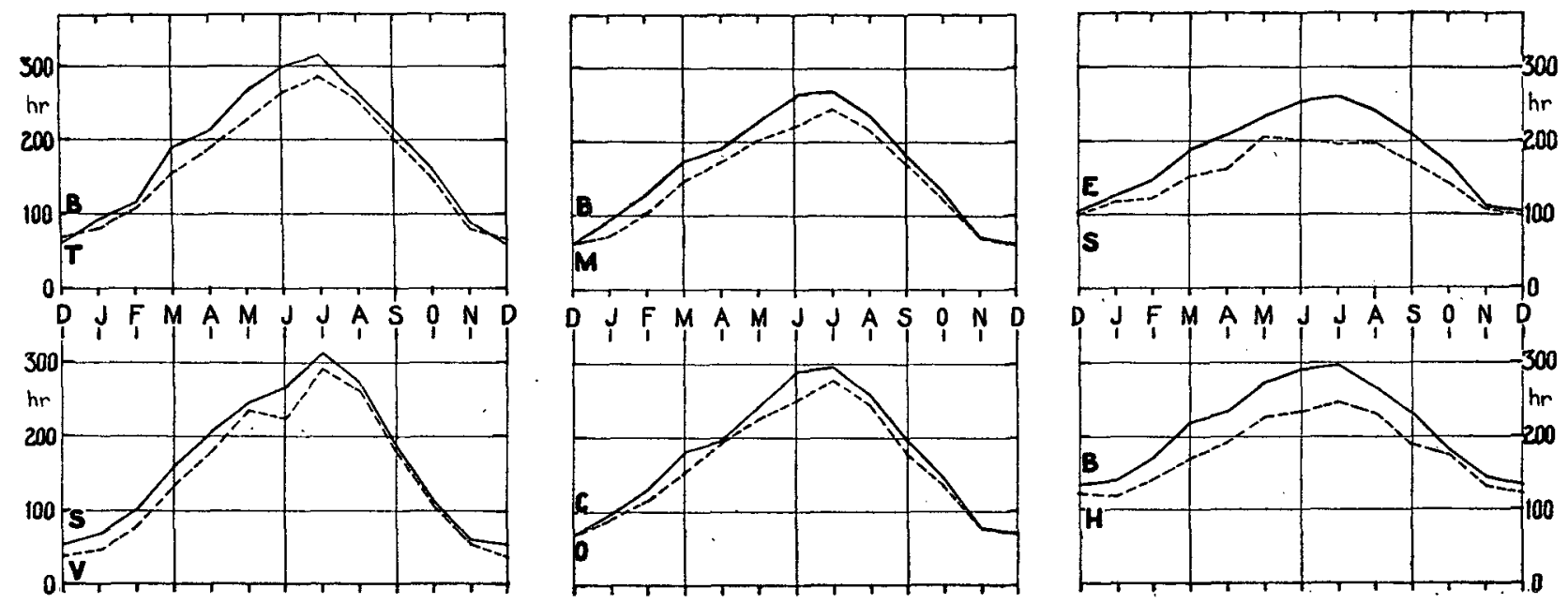

FIG. 5. Annual course of sunshine duration at pairs of adjacent stations in Canada (CS, dashed lines) and United States (US, continuous lines): (B) Buffalo, N. Y., (T) Toronto, Ont.; (B) Burlington, Vt., (M) Montreal, P. Q.; (E) Eastport, Me., (S) St. John, N. B.; (S) Seattle, Wash., (V) Vancouver, B. C.; (C) Canton, N. Y., (O) Ottawa, Ont.; (B) Boston, Mass., (H) Blue Hill, Milton, Mass.

any other paired stations, and both have long records.

In Mexico, the CS is used at all solar stations except Tacubaya, but the Mexican stations are too distant to be satisfactorily paired with any in the United States. At Tacubaya, the CS was replaced by a US in April 1921. The comparison (table 13) of CS and US Tacubaya records, necessarily for different periods, is based on published official Mexican data compiled by Dr. W. Gorczynski (cf. 1932a; 1932b).

The conversion values derived from the Mexican records are mostly larger than those for the northern stations in table 12. A similar contrast appears in table 11 . In the south, more summery weather prevails, which increased the US record relative to the CS. The seasonal curve for Tacubaya shows that February to April is the sunniest season and June to October

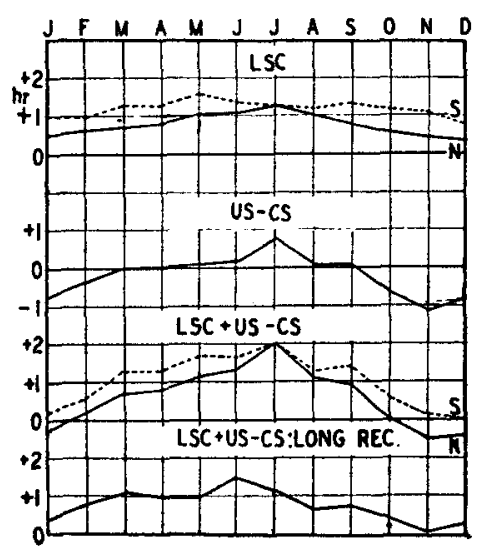

FIG. 6. Factors in conversion values: (LSC) Low-sun correction, averages for southern (dashed line) and for northern stations (continuous line). (US - CS) Instrument difference at Blue Hill: in detail, $\frac{1}{2}\left(U^{2} S_{1}+U S_{2}\right)-C S$; equivalent to $C S-\frac{1}{2}\left(U_{1}+U_{1}\right)$ inverted. (LSC + US - CS) Sum of the two curves above, i.e., conversion value based on low-sun correction and instrument difference. (LSC + US - CS: LONG REC.) Conversion values based on long Canadian and United States records shown in fig. 5 and table 12 . the most cloudy, weather type being a more important control at this latitude $\left(19^{\circ} \mathrm{N}\right)$ than length of day.

The conversion values obtained from table 12 show a seasonal curve (fig. 6) similar to those computed from the LSC and instrument difference, but not so steep. Note that it is not a smooth curve, but has shoulders on each side of a central peak. This feature may be connected with the spring and fall resetting of the US instrument. The values are perhaps too large for the north in winter, for they should not exceed the LSC except when US exceeds CS, a situation characteristic of summer months only (see fig. 3).

It is likely, however, that the instrument difference obtained at Blue Hill in winter is too large to be typical. Winter is the season in which CS registers highest relative to US. At Blue Hill, above city smoke, this difference is probably accentuated. In cities, CS would not register as near sunrise or sunset as it does on Blue Hill. US, starting usually with the sun at a higher angle; might be less delayed by smoky lower air. This is one explanation for the steeper curve of the conversion values obtained from LSC and the instrument difference (fig. 6).

\section{Instrumental and station conversion values}

The conversion values obtained in tables 11-13 are summarized in tables 14 and 15 . We have presented not only different conversion values but also data from which more can be calculated. There is no entirely satisfactory method of reducing US to CS, because CS measures direct sunlight only, and US, direct plus diffuse.

Although the conversion values for the northern and southern groups of stations in the United States are well based as far as LSC is concerned, the use of the Blue Hill hilltop comparison of the two US instruments with one CS is a less adequate foundation for 
TABLE 14. Instrumental and station conversion values, in hours, by months.

\begin{tabular}{|c|c|c|c|c|c|c|c|c|c|c|c|c|c|}
\hline Stations & Jan. & Feb. & March & April & May & June & July & Aug. & Sept. & Oct. & Nov. & Dec. & Year \\
\hline \multicolumn{14}{|c|}{ Basis: Instrument comparisons at Blue Hill (table 11) } \\
\hline $\begin{array}{l}\text { Northern United States } \\
\text { Southern United States }\end{array}$ & $\begin{array}{l}-0.3 \\
-0.2\end{array}$ & $\begin{array}{l}0.2 \\
0.5\end{array}$ & $\begin{array}{l}0.6 \\
1.2\end{array}$ & $\begin{array}{l}0.8 \\
1.3\end{array}$ & $\begin{array}{l}1.2 \\
1.7\end{array}$ & $\begin{array}{l}1.3 \\
1.6\end{array}$ & $\begin{array}{l}2.1 \\
2.1\end{array}$ & $\begin{array}{l}1.2 \\
1.3\end{array}$ & $\begin{array}{l}1.0 \\
1.5\end{array}$ & $\begin{array}{l}0.1 \\
0.7\end{array}$ & $\begin{array}{r}-0.3 \\
0.3\end{array}$ & $\begin{array}{r}-0.3 \\
0.1\end{array}$ & $\begin{array}{l}0.6 \\
1.0\end{array}$ \\
\hline \multicolumn{14}{|c|}{ Basis: Difference in long records (tables 12,13$)$} \\
\hline $\begin{array}{l}\text { United States - Canada ( } 5 \text { pairs) } \\
\text { Boston - Blue Hill }\end{array}$ & $\begin{array}{l}0.4 \\
0.5\end{array}$ & $\begin{array}{l}0.7 \\
1.0\end{array}$ & 1.0 & $\begin{array}{l}0.8 \\
1.3\end{array}$ & $\begin{array}{l}0.8 \\
1.4\end{array}$ & $\begin{array}{l}-1.4 \\
1.8\end{array}$ & $\begin{array}{l}1.1 \\
1.5\end{array}$ & $\begin{array}{l}0.5 \\
1.1\end{array}$ & $\begin{array}{l}0.5 \\
1.3\end{array}$ & $\begin{array}{l}0.4 \\
0.6\end{array}$ & $\begin{array}{l}0.1 \\
0.2\end{array}$ & $\begin{array}{l}0.2 \\
0.4\end{array}$ & $\begin{array}{l}0.65 \\
1.0\end{array}$ \\
\hline $\begin{array}{l}\text { Combined average, } \\
\frac{2}{3}(\text { U.S. - Can. })+\frac{1}{3}(\text { B. }- \text { B.H. }) \\
\text { Tacubaya, Mexico }\end{array}$ & $\begin{array}{l}0.4 \\
1.2\end{array}$ & $\begin{array}{l}0.8 \\
1.2\end{array}$ & $\begin{array}{l}1.1 \\
2.2\end{array}$ & $\begin{array}{l}1.0 \\
2.4\end{array}$ & $\begin{array}{l}1.0 \\
1.8\end{array}$ & $\begin{array}{l}1.5 \\
1.9\end{array}$ & $\begin{array}{l}1.2 \\
1.1\end{array}$ & $\begin{array}{l}0.7 \\
0.5\end{array}$ & $\begin{array}{l}0.8 \\
0.6\end{array}$ & $\begin{array}{l}0.5 \\
0.7\end{array}$ & $\begin{array}{l}0.1 \\
0.8\end{array}$ & $\begin{array}{l}0.3 \\
1.6\end{array}$ & $\begin{array}{l}0.8 \\
1.3\end{array}$ \\
\hline
\end{tabular}

TABLE 15. Instrumental and station conversion factors, in hours, by seasons.

\begin{tabular}{|c|c|c|c|c|c|}
\hline Station & Winter & Spring & Summer & Autumn & Year \\
\hline \multicolumn{6}{|c|}{ Basis: Instrument comparisons at Blue Hill } \\
\hline Northern United States & -0.1 & 0.9 & 1.5 & 0.2 & 0.6 \\
\hline \multirow[t]{2}{*}{ Southern United States } & 0.3 & 1.4 & 1.7 & 0.8 & 1.0 \\
\hline & in long & & & & \\
\hline United States - Canada & 0.4 & 0.9 & 1.0 & 0.3 & 0.65 \\
\hline Boston - Blue Hill & 0.6 & 1.4 & 1.5 & 0.7 & 1.0 \\
\hline Combined average, $\frac{2}{3}$ (U.S. - Can. $)+\frac{1}{3}($ B. - B.H. $)$ & 0.5 & 1.0 & 1.2 & 0.5 & 0.8 \\
\hline Tacubaya, Mexico & 1.3 & 2.1 & 1.2 & 0.7 & 1.3 \\
\hline
\end{tabular}

estimating the general difference between the average US and the average CS. Therefore, we are inclined to favor the long-record comparisons as a more valid basis for interconverting sunshine-duration records by CS and US.

It may be noted that the long-record comparisons give an annual difference very close to the LSC; this fact indicates that the annual instrument difference in ordinary practice is negligible (see table 16).

To convert US to CS annual average, one might merely subtract the LSC, or about 11 per cent of the tabulated duration for the northern United States, increasing to perhaps 14 per cent for the south. If any large range of latitude or aridity is involved, the conversion value cannot be a flat rate, a percentage basis seeming better.

\section{Comments on instrumentation}

This study raises several questions with regard to instrumentation.

1. Should the recording of simply the duration of sunshine be continued? The answer seems to be: not if it is feasible to record the actual intensity as well as the duration. But the instruments and recorders for intensity are so expensive, not only in the first purchase, but also in maintenance and in the evaluation of the record, that to confine duration records to stations that could have recorders of intensity as well would be to restrict the network of sunshine stations unduly.

2. What should duration recorders be designed to record: (a) the duration of time that the sun is visible (US and low-sun correction); (b) the duration of bright direct sunshine (define 'bright') (CS); (c) the duration of bright sun and sky shine (define 'bright,' of which the bright sunshine is at normal incidence) (US); (d) same as (c) except measurement is made on a horizontal surface (US if bulbs flattened and exposed horizontally)? The answer depends on the answer to another question: Are we more interested in (a) illumination, (b) direct sunshine alone, (c) insolation on a person, or (d) insolation on the ground? The last mentioned comes closest to the ultimate desideratum for radiation data in meteorology, and it could be measured by a US type with bulbs flattened and exposed

TABLE 16. Comparison of low-sun corrections, conversion values, and sunshine duration (annual values).

\begin{tabular}{|c|c|c|c|c|}
\hline Station pairs & $\begin{array}{l}\text { Low-sun } \\
\text { correction }\end{array}$ & $\begin{array}{c}\text { Conversion } \\
\text { value* }\end{array}$ & $\begin{array}{l}\text { Tabulated } \\
\text { duration } \\
\text { (US +LSC) }\end{array}$ & $\begin{array}{c}\text { Ratio, } \\
\text { conv. val. } \\
\text { to tab. } \\
\text { dur. }\end{array}$ \\
\hline $\begin{array}{l}\text { Burlington, Vt. } \\
\text { B. to Montreal, P. Q. }\end{array}$ & 0.5 & 06 & 5.6 & 11 \\
\hline $\begin{array}{l}\text { Buffalo, N. Y. } \\
\text { B. to Toronto, Ont. }\end{array}$ & 0.6 & $0=$ & 6.2 & 8 \\
\hline Seattle, Wash. & 0.6 & & 5.6 & \\
\hline $\begin{array}{l}\text { Boston, Mass. } \\
\text { B. to Blue Hill, Mass. }\end{array}$ & 0.8 & 1.0 & 7.2 & 14 \\
\hline $\begin{array}{l}\text { Northern average } \\
\text { Southern average }\end{array}$ & $\begin{array}{l}0.8 \\
1.2\end{array}$ & 0.8 & $\begin{array}{l}7.0 \\
8.7\end{array}$ & $\begin{array}{l}11 \\
14\end{array}$ \\
\hline Tacubaya, Mexico & & 1.3 & 7.1 & 18 \\
\hline
\end{tabular}

* Subtract from (US + LSC) to get CS.

$\dagger$ From table 8.

horizontally, 4 provided that the instruments were either set to a standard insolation value before issue to stations or set to register when exposed to a new 100-watt electric light bulb of stated type at a vertical

${ }^{4}$ Mr. Irving F. Hand, of the U.S. Weather Bureau, has pointed out that US would be more effective if, instead of being a cylindrical tube, it were elliptical, presenting a broad surface east and west to the early and late sun. (Personal communication.) 
distance that would give the limiting value of insolation desired.

Acknowledgments. - The preparation of this study was facilitated by grants from the Associates in Physical Sciences, Harvard University, and from the Geophysical Research Fund of the Blue Hill Meteorological Observatory.

Dr. W. Gorczynski aided in preparing the introduction, description of instruments, and bibliography, and compiled the data for Tacubaya.

\section{REFERENCES}

Braak, C., 1937: The climate of the Netherlands. $K$. ned. meteor. Inst. Meded. Verh., 40, 51 pp. (see pp. 40-43).

Curtis, R. H., 1898: Sunshine recorders and their indications. Quart. J. R. meteor. Soc., 24, 1-30.

-.-, 1909: The standardization of sunshine recorders. Meteor. Mag. (London), 44, 187-191; 204-206.
Glasspoole, J., and D. S. Hancock, 1936: The distribution over the British Isles of the average duration of bright sunshine. Quart. J. R. meteor. Soc., 62, 247-259.

Gorczynski, W., 1932a: Radiación solar en Tacubaya. Sunshine climate of Mexico, Servicio Meteorológico Mexicano.

-_, 1932b: Radiación solar total y difusa en Tacubaya, etc. Ibid.

- 1943: Sunshine and cloudiness in the Mediterranean Basin. Bull. Amer. meteor. Soc., 24, 183-193.

-_, 1945: Comparisons of climate of the United States and Europe. Polish Institute of Arts and Sciences in America, $288 \mathrm{pp}$.

Maring, D. T., 1897: An improved sunshine recorder. Mon. Wea. Rev., 25, 485-490 (see p. 487).

Marvin, C. F., 1941: Instructions for the care and management of electrical sunshine recorders. Washington, U. S. Weather Bureau, Circular G, 11 pp.

Meteorological Office, 1934: The observer's handbook. London, 152 pp. (see pp. $94-102$, pls. VII-IX).

Neuberger, Hans, 1945: Notes on the determination of the effectively possible duration of sunshine. Bull. Amer. meteor. Soc., 26, 74-75.

Selga, Miguel, 1928: The sunshine of Manila. Manila, Weather Bureau, Manila Central Observatory, 22 pp. (see p. 9). 